\title{
Estimation of Accident Frequency at Newly-built Roundabouts in the Czech Republic
}

\author{
P. Šenk* \& J. Ambros \\ Transport Research Centre, Brno, Czech Republic \\ * Corresponding author: petr.senk@cdv.cz
}

DOI: $10.2478 / \mathrm{v} 10158-011-0018-4$

\begin{abstract}
Roundabouts have become one of the most popular traffic easing and safety improving measures implemented on roads in the Czech Republic. The decision on he ealization of each new roundabout should be based on the knowledge of the expected realization costs and benefits resulting from the future operation, especially changes in traffic and safety performance. This study introduces a negative binomial regression model that enables the quantification of the safety performance of roundabouts in terms of accident frequency in relation to their traffic and geometric characteristics. Model design and estimation of parameters is based on the sample of 90 roundabouts situated on all types of roads in the Czech Republic. Results suggest that the number of accidents depends on the number of lanes on entering arms, vehicle speed in the vicinity of roundabouts, width of traversable apron and, of course, also on the annual average daily traffic. Resulting model structure is in accordance with structures of accident prediction models used in other EU countries and the US. Certain differences can be found in the degree of effects of particular model variables.
\end{abstract}

KEY WORDS: accident prediction model, roundabout, negative binomial model.

\section{INTRODUCTION}

Road intersections are one of the most risky parts of road networks; according to iRAP's Road Safety Toolkit (iRAP, 2010), intersection accidents are one of the most common types of accidents worldwide. Retting et al. (1999) report that about $40 \%$ of motor vehicle crashes in the US occur at intersections or are intersection-related. According to Czech Police data, approximately $25 \%$ of all accidents happen at intersections. The underlying level of risk is closely related to the number of conflict points and lower speed of passing vehicles. For that reason, the conversion of level intersections to roundabouts is one of the most popular safety measures. At a roundabout the driver has to travel in one direction around a central island, which minimizes the number of conflict points.

Several studies have shown that the conversion of intersections to roundabouts is associated with substantial reductions in the number of accidents. For example, Schoon \& van Minnen (1994) analyzed 181 Dutch intersections and found a $47 \%$ reduction. In the before-and-after study of the conversion of 23 roundabouts in the US, Persaud et al. (2001) identified a $40 \%$ decrease in the number of accidents compared to the previous intersections. Elvik's (2003) meta-analysis of 28 studies of non-US roundabout conversions 
showed a reduction of fatal accidents by 50 to $70 \%$. As for the Czech Republic, results of research project BESIDIDO (Pokorný, 2011) showed on the sample of 8 conversions from intersections to roundabouts a reduction in accident frequency of $36 \%$.

The degree of the safety benefit of roundabouts seems to depend on their geometrical parameters. Results of Elvik's above-mentioned meta-analysis showed that the majority of small roundabouts (a small diameter of the central traffic island) are safer than large roundabouts (a large diameter of the central traffic island). According to TRB's (1998) the synthesis of world-wide roundabout experience, safety benefits seem to be greatest for single-lane roundabouts in rural conditions.

The first roundabouts in the Czech Republic started to appear about 20 years ago. Up to now, there are approximately 3000 roundabouts designed according to various guidelines (V-projekt, s.r.o., 2000, Centrum dopravního výzkumu, v.v.i., 2005, CityPlan spol. s r. o., 2009). None of them, however, deals with the assessment of road safety.

The main objective of the study is to develop a tool that will enable the quantification of safety at roundabouts in the Czech Republic. In the results we will be able to say what geometric or traffic parameters influence the expected number of accidents at roundabouts and what is the degree of the influence. The next section presents data used for the analysis, after that follows a short description of methods applied in accident prediction models and results of the analysis. The paper is concluded by discussion of results.

\section{DATA}

The study integrates data from several sources - data on road accidents, data on road geometry and data on traffic volumes.

Data on road accidents come from the database of the Police of the Czech Republic. Each record contains information on location, involved parties, type of accident, injuries and property damage. Due to the recent change in the methodology of data collection (since 1st of January, 2009 the property damage limit when an accident has to be reported to police changed from $50000 \mathrm{CZK}$ to $100000 \mathrm{CZK}$ ), only accident data from years 2009 and 2010 were used in the analysis. During the data preparation phase all incomplete and defective records were removed; only accidents within $100 \mathrm{~m}$ radius from the nearest observed roundabout were selected knowing that the maximum radius of roundabouts in the dataset is $73 \mathrm{~m}$; and finally three accidents involving pedestrians were removed due to missing data on pedestrian flows. The resulting road accident dataset consists of 188 records corresponding to 136 accidents without injury, 44 accidents with one slight injury, 5 accidents with two or three slight injuries and 3 accidents with one serious injury. Please note that as property damage-only accidents up to $100000 \mathrm{CZK}$ (about $4000 \mathrm{EUR}$ ) are not being registered, they are not included in the analysis.

The sample of 90 roundabouts was selected in two steps on a non-probability base. First, all roundabouts from the database of the Road and Motorway Directorate of the Czech Republic (RSD) with known traffic flow data on all entering arms and no construction adjustments since 1st of January 2009 (48 out of the total of 286 roundabouts) were selected. In order to correct for the lower number of roundabouts with arms that are not registered in the RSD database, another 42 roundabouts surveyed within the mentioned previous project BESIDIDO were added to the sample. As there is no central database of all roundabouts in the Czech Republic, the additional sample is a result of a detailed search using web map applications.

Data on road and roundabout geometry are from two data sources. Basic data on first, second and third class roads and respective roundabouts were provided by the RSD. Additional data were collected using Google Earth that enables a reasonably precise 
estimation of road geometry. Details of the data, including key descriptive statistics, are shown in Table 1.

Table 1: Descriptive statistics of geometrical, traffic, and accident data.

\begin{tabular}{|l|l|l|l|l|}
\hline Denotation & Description & Variable type [Units] & Source * & $\begin{array}{l}\text { Descriptive statistics } \\
\text { (mean/SD/min/max or } \\
\text { counts of binary values })\end{array}$ \\
\hline AADT & AADT at roundabout & Continuous [veh/year] & RSD/B & $17993 / 9873 / 3181 / 52952$ \\
\hline URBAN & Urban area & Binary [1=URBAN] & RSD & $1: 80 ; 0: 10$ \\
\hline LANES_R & Two-lane roundabout & Binary [1=YES] & GE & $1: 6 ; 0: 84$ \\
\hline LANES_A & Arm with two lanes & Binary [1=YES] & GE & $1: 5 ; 0: 85$ \\
\hline OUTER_D & Outer diameter & Continuous [m] & GE & $42 / 24 / 18 / 146$ \\
\hline BYPASS & Bypass present & Binary [1=YES] & GE & $1: 15 ; 0: 75$ \\
\hline ANGLE & $\begin{array}{l}\text { Max. angle between } \\
\text { arms }\end{array}$ & Continuous [degree] & GE & $118 / 25 / 65 / 180$ \\
\hline APRON & Traversable apron width & Continuous [m] & GE & $2.1 / 1.2 / 0 / 6$ \\
\hline ISLAND & Central island diameter & Continuous [m] & GE & $24 / 23 / 7 / 120$ \\
\hline ARMS & Number of arms & Continuous & GE & $4 / 0.6 / 3 / 6$ \\
\hline CRASH & Accident frequency & Continuous [acc./2years] & PCR & $2.1 / 3.6 / 0 / 22$ \\
\hline
\end{tabular}

* RSD - Road and Motorway Directorate of the Czech Republic; B - project BESIDIDO; GE - Google Earth; PCR - Police of the Czech Republic

Data on annual average daily traffic (AADT) on entering the arms of the roundabouts are from two sources. The main source is the National Traffic Census from 2005 that contains data on all first, second and third class roads. Information about the AADT on roads that were not found in the census comes from the internal survey executed within the project BESIDIDO in 2001-2004 (Simonová \& Hrubý, 2004). In order to get AADT values corresponding to the year 2010, all values were multiplied by coefficients of annual traffic growth published by Ministry of Transport (2005) for surveys executed in 2000 to 2004 and Road and Motorway Directorate (2005) for data from 2005 National Traffic Census.

\section{METHODOLOGY}

The aim of the study was to identify geometric and traffic variables that influence the safety of roundabouts and quantify the size of the corresponding effect. This task was solved by means of regression modeling, where the set of geometric and traffic variables was used to estimate the expected value of accident frequency at a given roundabout.

The basic form of the regression model was selected with respect to the characteristics of the response variable (accident frequency) and the standard practice in accident prediction modeling. Data on accident frequency take the form of count data. Literature on count data modeling (Kennedy, 2008) suggests the log-linear Poisson model as an appropriate choice provided that the variance and the expected value of response variable are of about the same value. The model is described as a generalized linear model (GLM), where the response variable $Y$ has a Poisson distribution with parameter $\lambda$ and takes non-negative integer values $y$ with probability

$$
\operatorname{Pr}\{Y=y\}=\frac{e^{-\lambda} \lambda^{y}}{y !}
$$

for $\lambda>0$. It can be shown that

$$
E(Y)=\operatorname{var}(Y)=\lambda
$$


which means that data suitable for Poisson regression violate the assumption of homoscedasticity required in classical linear regression models.

Finally, the linear combination of explanatory variables $\mathbf{x}$ and unknown parameters $\beta$ is related to the response variable via log-linear link function

$$
\ln (\lambda)=\mathbf{x} \beta
$$

that ensures non-negative values of parameter $\lambda$ and thus non-negative expected values of counts. Exponentiation of the formulae leads to the mean function

$$
\lambda=e^{\mathbf{x} \beta}
$$

expressing the relation between the linear predictor $\mathbf{x} \beta$ and the expected value of response variable. The vector of model parameters $\beta$ is estimated using maximum likelihood estimation method. Kmenta (1986) provides more technical details on the topic.

The variance of accident frequency in our data is about 1.7 times higher than the mean, suggesting that the basic assumption of Poisson regression on the equality of these two statistics is violated. Indeed, so called overdispersion appears in most data on accident frequency (Zhang et al., 2007). The problem was solved by a slight change of the model specification, through the introduction of unobserved heterogeneity into the mean function, so that

$$
\lambda=e^{(\mathrm{x} \beta+\varepsilon)}
$$

where $e^{\varepsilon}$ is a gamma distributed error with mean equal to unity and variance $\alpha$. Integration of $\varepsilon$ out of the specification leads to the negative binomial distribution for the number of observed traffic accidents with mean $\lambda$ and variance $\lambda+\alpha \lambda^{2}$. Positive values of parameter $\alpha$ correct for overdispersion in data, while values close to zero lead to the above described Poisson model. Parameters $\alpha$ and $\beta$ of the model were estimated using a maximum likelihood estimation method.

Several negative binomial models with all theoretically plausible combinations of explanatory variables were estimated using available data. All models include an exposure variable in the form of a natural logarithm of AADT and the set of geometric and location specifications. The logarithmic form of AADT ensures zero expected accident frequency in the case of the zero value of AADT. The basic specification of the expected accident frequency takes the form

$$
\lambda=A A D T^{\beta_{1}} \cdot e^{\gamma+\sum_{i=2}^{n} \beta_{i} \cdot x_{i}}
$$

with $\gamma$ as an intercept. The goodness-of-fit of estimated models was evaluated using Akaike information criterion (AIC). Moreover, a likelihood ratio test was used to test whether the difference between the fit of the two best performing models is significantly high.

The proportion of variability in data explainable by the model (systematic variation) and proportion of systematic variation explained by the model was calculated using FreemanTukey goodness-of-fit measure for systematic variation in Poisson regression models. Details on the calculation of Freeman-Tukey $\mathrm{R}^{2}$ are provided in Freeman and Tukey (1950). 


\section{RESULTS}

The model with the best fit to the data at hand and all coefficients of explanatory variables different from zero at 0.1 significance level is presented in Table 2.

Table 2: Explanatory variables and parameter estimates of the resulting model.

\begin{tabular}{|l|r|r|r|r|}
\hline $\begin{array}{l}\text { Explanatory } \\
\text { variable } x_{i}\end{array}$ & Estimate $\beta_{i}$ & Std. Error & $z$ value & $\operatorname{Pr}(>|z|)$ \\
\hline (Intercept) & -1.91 & 2.04 & -0.94 & 0.349 \\
\hline AADT & 0.39 & 0.21 & 1.82 & 0.068 \\
\hline URBAN & -1.27 & 0.30 & -4.18 & $<0.001$ \\
\hline APRON & -0.17 & 0.10 & -1.74 & 0.082 \\
\hline LANES_A & 1.66 & 0.39 & 4.21 & $<0.001$ \\
\hline & 322.04 & & & \\
\hline AIC & 2.12 & & & \\
\hline Estimate $\alpha$ & 0.83 & & & \\
\hline Std. Error $\alpha$ & -310.04 & & & \\
\hline 2 x Log-Likelihood & & & & \\
\hline
\end{tabular}

The positive value of the dispersion parameter and the respective standard error confirm the overdispersion of the response variable and justifies the use of a negative binomial model.

In accordance to other empirical studies (TRB, 2007, Daniels et al., 2010, 2011) and manuals on road safety at roundabouts (Eenink et al., 2008, Maycock \& Summersgill, 1994), AADT, as the exposure variable, is one of the key factors in the accident prediction model with a positive impact on the expected number of traffic accidents.

As for the location and geometric attributes of roundabouts, three variables turned out to be significant - URBAN, APRON and LANES_A. Roundabouts in urban areas appear to be safer than roundabouts in rural areas. It stands to reason that the location itself doesn't improve safety, but rather that URBAN is just a proxy for another unobserved variable, most likely the difference in the average speed of vehicles approaching the roundabout. Roundabouts in urban areas with a speed limit of $50 \mathrm{~km} / \mathrm{h}$ seem to be safer than roundabouts in rural areas, where the maximum speed in the immediate vicinity may reach up to $90 \mathrm{~km} / \mathrm{h}$. Furthermore, roundabouts with two-lane traffic on one of the entering arms (LANES_A) perform significantly worse in terms of road safety than roundabouts with single-lane traffic on all arms. And finally, the width of apron (APRON) has a positive effect on the number of observed accidents.

Figure 1 depicts the relation between the expected accident frequency in the time interval of two years (CRASH) and the continuous variables AADT and APRON in the case of the most common type of roundabouts in the Czech Republic - urban roundabouts with all single-lane entering arms. As can be seen, the accident frequency increases with AADT, while the growing width of apron (APRON) pushes its values down towards zero. Please note that expected annual accident frequency can be calculated by simple multiplication of the variable CRASH by a factor of 0.5 . 


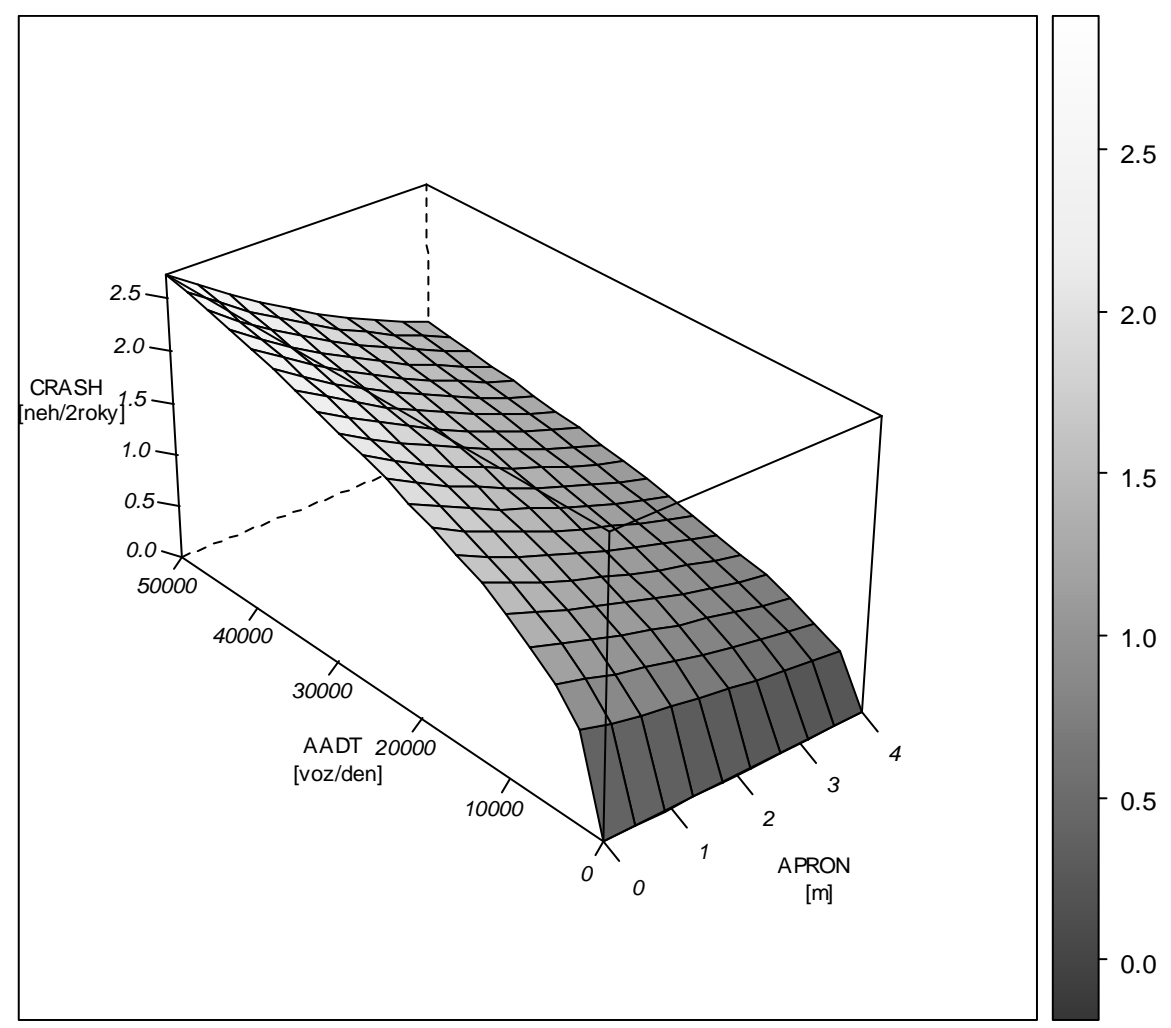

Figure 1: Relation between expected accident frequency, AADT and apron width in the case of urban roundabouts with all single-lane entering arms.

An overview of the resulting specifications of accident prediction models is presented in Table 3. Please note that the model specification for roundabouts in rural areas with twolane traffic on one of its arms is omitted due to their rarity.

Table 3: Overview of model specifications by location and type of entering arms.

\begin{tabular}{|c|c|c|}
\hline Location & Two-lane entering traffic & Model specification \\
\hline Urban & Yes & CRASH $_{1 \text { year }}=0.11 \cdot A A D T^{0.39} \cdot e^{-0.17 \cdot A P R O N}$ \\
\hline Urban & No & CRASH $_{1}$ vear $=0.02 \cdot A A D T^{0,39} \cdot e^{-0,17, A R R O N}$ \\
\hline Rural & No & $C R A S H_{1}$ vear $=0,07 \cdot A A D T^{0,39} \cdot e^{-0,17, A P R O N}$ \\
\hline
\end{tabular}

Value of $C A A S E_{1}$ rear refers to expected number of accidents within one year.

The ability of the model to explain the variation in the data was evaluated using FreemanTukey $\mathrm{R}^{2}$. Results showed that within $66 \%$ of "explainable" systematic variation present in the data, $41 \%$ is explained by our model.

\section{SUMMARY AND DISCUSSION}

The aim of the study was to develop accident prediction models suitable for roundabouts in the Czech Republic. The resulting negative binomial regression model involves accident frequency as a response variable and AADT, location, number of traffic lanes, and apron width as explanatory variables. Results showed that in the case of car-only accidents roundabouts in urban areas appear to be safer than roundabouts in rural areas, probably due to different speed limits in the vicinity. The accident frequency is also higher for roundabouts 
with two-lane approaches. This is consistent with general experience that multi-lane roundabouts provide higher number of conflict points and more space for lane changing and higher speed (TRB, 2010). Finally, the accident frequency seems to decrease with the growing width of the traversable apron. Aprons slow down vehicles passing straight through the junction, which has in result a positive effect on safety. To sum up, the safest roundabouts in the Czech Republic are the urban ones with a single lane and wider apron.

It is worth mentioning that, with respect to the diversity of geometric and traffic characteristics of roundabouts, the sample used in the analysis is admittedly too small for a mechanical generalization of results. Accident prediction models introduced in the study fit the most common types of roundabouts in the Czech Republic relatively well. Descriptive statistics in Table 1 can serve as a clue as to what is meant by the word "common". Application of the prediction model to atypical roundabouts should be done with special caution.

A relatively low percentage of explained systematic variation in data may be attributed to other, non-geometrical attributes related to accident frequency, such as behavior of local drivers, weather conditions, etc. Moreover, available data didn't provide enough details for a separate analysis of safety at roundabouts themselves and safety on adjacent arms. Most accident prediction models for roundabouts account for interaction among entering traffic flow and traffic flow circulating at the junction (Turner, 2000, TRB, 2007). The collection of data that will enable the comparison of specification and parameter estimates of the accident prediction model for roundabouts in the Czech Republic with accident prediction models applied in other countries is thus a challenge for future studies on the topic.

\section{REFERENCES}

Centrum dopravního výzkumu, v.v.i., 2005. Metodický pokyn „Velké okružní křižovatky“. Centrum dopravního výzkumu, v.v.i., Brno.

CityPlan spol. s r. o., 2009. Přiručka pro navrhování okružních křižovatek [online]. c2009 [cit. 2011-06-22]. <http://www.cityplan.cz/index.php?id_document=1372>.

Daniels, S., Brijs, T., Nuyts, E., Wets, G., 2010. Explaining variation in safety performance of roundabouts. Accident Analysis and Prevention, vol. 42, iss. 2, pp. 393 - 402.

Daniels, S., Brijs, T., Nuyts, E., Wets, G., 2011. Extended prediction models for crashes at roundabouts, Safety Science, vol. 49, iss. 2, pp. $198-207$.

Eenink, R., Reurings, M., Elvik, R., Cardoso, J., Wichert, S., Stefan, C., 2008. Accident Prediction Models and Road Safety Impact Assessment: recommendations for using these tools [online]. c2008 [cit. 2011-06-22]. <http://ripcord.bast.de/pdf/RIPCORD-ISERESTDeliverable-D2-Final.pdf $>$.

Elvik, R., 2003. Effects on road safety of converting intersections to roundabouts: review of evidence from non-U.S. studies. Transportation Research Record, vol. 1847, pp. 1 - 10.

Freeman, M. F., Tukey, J. W., 1950. Transformations related to the angular and the square rood. Annals of Mathematical Statistics. Vol. 21, pp. 607 - 611.

iRAP, 2010. Road Safety Toolkit: Intersections [online]. c2010 [cit. 2011-06-22]. $<$ http://toolkit.irap.org/default.asp?page $=$ crashtype\&id $=8>$.

Kennedy, P., 2008. A Guide To Econometrics, 6th Edition. Blackwell Publishing, p. 246.

Kmenta, J., 1986. Elements of Econometrics, 2nd Edition. Prentice Hall, pp. 175 - 183. 
Maycock, G., Summersgill, I., 1994. Methods for investigating the relationship between accidents and road design standards. Transport Research Laboratory, Crowthorne.

Ministry of Transport, 2005. Základní data pro výpočty ekonomické efektivnosti silničních a dálničních staveb v investičních záměrech s použitím programu HDM-4 s kalibrovanými daty (CSHS) [online]. c2005 [cit. 2011-06-22]. <www.mdcr-vyzkuminfobanka.cz/DownloadFile/2010.aspx>.

Persaud, B. N., Retting, R. A., Garder, P. E., Lord, D., 2001. Safety effect of roundabout conversions in the United States: Empirical Bayes observational before-after study. Transportation Research Record, vol. 1751, pp. $1-8$.

Pokorný, P., 2011. Cost-benefit analysis of implementation of four-arm roundabouts in urban areas. Transactions on Transport Sciences, vol. 4, iss. 2 (in press).

Retting, R. A., Ulmer, R. G., Williams, A. F., 1999. Prevalence and characteristics of red light running crashes in the United States. Accident Analysis and Prevention, vol. 31, iss. 6 , pp. $687-694$.

Road and Motorway Directorate, 2005. Výhledové koeficienty růstu dopravy pro obdobi 2005 - 2040 pro dálnice a rychlostni silnice [online]. c2005 [cit. 2011-06-22]. $<$ http://www.rsd.cz/rsd/rsd.nsf/0/d795e8881160bae5c1256e230048ef83/\$FILE/P\%C5\%9 9\%C3\%ADloha\%20D.doc $>$.

Schoon, C., van Minnen, J., 1994. The Safety of Roundabouts in the Netherlands. Traffic Engineering and Control, vol. 35, iss. 3, pp. $142-148$.

Simonová, E., Hrubý, Z., 2004. BESIDIDO - Moderni úpravy komunikací ve městech a obcích pro zklidňování, vyšši bezpečnost a estetickou úroveñ. Silniční obzor, vol. 65, iss. 5, pp. $132-133$.

TRB, 1998. Modern Roundabout Practice in the United States: A Synthesis of Highway Practice (NCHRP Synthesis 264). Transportation Research Board and National Research Council, Washington, D. C.

$<$ http://onlinepubs.trb.org/onlinepubs/nchrp/nchrp_syn_264.pdf $>$.

TRB, 2007. Roundabouts in the United States (NCHRP Report 572), Transportation Research Board, Washington, D. C. <http://trb.org/publications/nchrp/nchrp_rpt_572.pdf>.

TRB, 2010. Roundabouts: An Informational Guide, Second Edition (NCHRP Report 672), Transportation Research Board, Washington, D. C.

$<$ http://onlinepubs.trb.org/onlinepubs/nchrp/nchrp_rpt_672.pdf $>$.

Turner, S. A. Accident Prediction Models (Transfund New Zealand Research Report No. 192). Transfund NZ, Wellington.

V-projekt, s.r.o., 2000. Projektování okružních křžovatek na silnicích a místních komunikacich (Technické podmínky 135). V-projekt, s.r.o., Ostrava.

Zhang, Y., Ye, Z., Lord, D., 2007. Estimating the Dispersion Parameter of the Negative Binomial Distribution for Analyzing Crash Data Using a Bootstrapped Maximum Likelihood Method. Transportation Research Record, vol. 2019, pp. 15 - 19.

\section{The article was produced under the support of the project}

Transport R \& D Centre ( CZ.1.05/2.1.00/03.0064 ). 